\title{
Düşünce ve İnanç Özgürlüğü: Dini Çoğunluk mu? Dinde Çoğulculuk mu? Eleştirel Bir Çözümleme
}

Şahin FILIIZ ${ }^{1}$

\section{$\ddot{O} z$}

Din ya da dinler, doğrudan doğruya insan ve özgürlük sorunların akla getirir. Yeryüzünde pek çok din vardır; bir kısmı tarihe gömülmüş, adı-sanı unutulmuş ama etkisi bu günlere kadar gelebilmiştir. Yine de bu gün ayakta kalan dinler epeycedir. Bunlar arasında diyalog, ilişki, çeşitlilik veya çoğulculuktan söz edilince sayısız varlıkları karşısında ne yapacağımızı bilemeyiz. O yüzden dinler ile yalnız üç Sami dini kastedeceğim. Sırasıyla Yahudilik, Hıristiyanlık ve İslam üç büyük din olarak kabul edilir. Bunların dışındaki dinlere haksızlık etmemek için, "üç büyük din" yerine, birbiri peşi sıra gelen üç Sami kaynaklı dinler grubu dersem yerinde bir adlandırma olacaktır. Çünkü dünyada bunlardan başka ve büyük de olan diğer dinler de vardır. Ama yazacağım bölümün sayfaları hepsini içeremeyecek kadar kısıtlı olduğundan çoğulculuk, çeşitlilik, diyalog, ilişki kavramlarını sırf bu dinler bağlaminda değerlendireceğim.

Anahtar Sözcükler: Din, Özgürlük, Çoğulculuk, İslam, insan

Freedom of Thought and Belief: Religious Pluralism? Pluralism in Religion? A Critical Analysis

Atıf/Reference: Şahin Filiz, “Düşünce ve İnanç Özgürlügü: Dini Çoğunluk mu? Dinde Çoğulculuk mu? Eleştirel Bir Çözümleme", Farabi Felsefe ve Din Bilimleri Dergisi, S.1, 2020,

1 Prof. Dr., Akdeniz Üniversitesi Edebiyat Fakültesi Felsefe Bölümü Öğretim Üyesi. 


\section{Summary}

Religion, or religions, directly brings to mind the problems of human and freedom. There are many religions on the earth; some of it is buried in history, its name has been forgotten, but its effect has survived to these days. Still, there are quite a few religions that survive today. Speaking of dialogue, relationship, diversity or pluralism among them, we cannot know what to do in the face of their numerous beings. So by religions I will only mean the three Semitic religions. Judaism, Christianity, and Islam, respectively, are considered to be the three major religions. In order not to be unfair to other religions, instead of "three great religions", if I say three consecutive Semitic religious groups, it would be a proper name. Because there are other great religions in the world as well. But since the pages of the chapter I will write are so limited that they cannot contain all of them, I will evaluate the concepts of pluralism, diversity, dialogue, and relationship only in the context of these religions.

Keywords: Religion, Freedom, Pluralism, Islam, human being.

Volney, din fenomeninin yüzyıllardır süren benzer durumunu duygusal ama gerçekçi bir dille şöyle betimler:

"Yeryüzünde kendilerine Tanrının sırdaşı diyen kalpazanlar türedi; bunlar, biz kavimlerin mürşidiyiz diye ortaya çıkıp yalana, hakkaniyetsizliğe yol açtılar: anlamsız ya da gülünç işleri değerlendirdiler; bir takım tavırlar takınmayı, bir takım sözler söylemeyi, bir takım adları hecelemeyi erdem diye gösterdiler; bazlları etlerle içkilerin belli günlerde yenilip içilmesini günah saydılar. Ey yüce ve gerçekten göğe dayanan doktrinler: Ey şehitliğe ve havariliğe yakışır yetkin ahlak kuralları! Bu eşsiz kanunları vahşi kavimlere, uzaklardaki milletlere öğretmek için denizler aşacă̆ım; onlara diyeceğim ki: Tabiatın çocukları! Bu cahillik yolunda daha ne kadar yürüyeceksiniz? Dinin, ahlakın gerçek ilkelerini daha ne

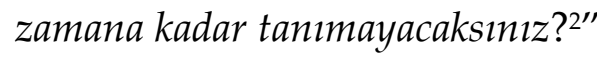

2 Volney, Harabeler, Çev. Kazım Akses, Milli Eğitim Basımevi, İstanbul, 1946, ss. 64, 65. 
Diyalog ve Çatışma... Dinler ve inançlar arası diyalog veya çatışmadan söz edebilir miyiz? Başka türlü sorayım. Farklı din ve dinlere bağlı insanlar bir arada yaşayabilir mi? Yoksa bu mümkün değil, kesinlikle çatışırlar diyebilir miyiz? İnançlar çatışır ya da uzlaşırlar mı? Bu sorularının hepsine hayır cevabı verebiliriz. Çünkü çatışan veya diyalog kuran, ne dinler, ne de inançlardır. Başka başka din ve inançlara sahip insanlar, ne çatışırlar, ne de aralarında pürüzsüz bir ittifak kurabilirler. O halde dini çoğulculuk nedir? Birden fazla dinlerin birlikte yaşaması mıdır? Yoksa dinler arasında inanç ilkeleri bakımından hiçbir fark olmadığı anlamına mı gelir? Bütün dinler inanç ilkeleri olarak eşit durumda mıdır?

\section{Dini çoğulculuk}

Bu kavram, dinlerin birlikte yaşama kültüründen çok, eşit doğruluk değerlerine sahip olması anlamına gelir. Dini çoğulculuğu daha iyi anlamak için bunun karşıtı ya da benzer anlamlarını içeren diğer kavramları görmek gerekir. Bunlardan birisi dini tekelciliktir. Exclusivism, Particularism ya da absolutism, dini tekelciliğin yabancı dildeki karşılıklarıdır. Bu karşılıklar, dini çoğulculuğun esasen Avrupa kültürüne ait olduğunu göstermektedir. Tekelciliğin çeşitleri vardır: katı tekelcilik yani dışlayıcılık, kendinden başka hiçbir dini doğru ve haklı görmemektir. Kapsayıcılık ya da ılımlı tekelcilik, katı tekelciliğe göre daha hoşgörülüdür; kendinden başka diğer bütün dinler yanlıştır ama onlara bir dereceye kadar hoş görü gösterilebilir. Çoğulculuk ya da aşırı ılımlı tekelcilik, kendini tek doğru din olarak görmekle birlikte başka dinlerin de doğru olabileceğini kabul eder. ${ }^{3}$

Ülkemizde dini çoğulculuk, genellikle John Hick'in başlattığı bir sorun olarak tartışılmaktadır. Başka bir deyişle, Avrupa'da Hıristiyanlığın öteki dinlerle ilişkisinde ortaya çıkan toplumsal ve teolojik problemler Türkiye'deki dini çoğulculuk tartışmalarının ana eksenini oluşturmaktadır.

3 David Basinger, Religious Diversity A Philosophical Assessment, Ashgate, NY., 2002, s. 5 ve devamı. 
John Hick'e göre fenomenolojik açıdan bakıldığında, geleneklerin ve her bir gelenek içerisindeki çeşitliliklerin çokluğunu anlatır. Felsefede büyük dünya dinleri tek bir tane olan nihai ve ilahi hakikatin çeşitli şekillerde dile getirilmesi ve onun karşısında da neler yapılabileceğinin birer anlatımı ve örneğidir. Hakikat her dinin ortak yasasıdır ve hiçbir din kendi başına hakikati temsilde yeterli değildir. ${ }^{4}$

Dini çoğulculuk, dini dışlayıcılığın karşıtıdır. Esasen her din ötekine göre dışlayıcıdır. Yahudilik, Hıristiyanlık ve İslam olmak üzere üç büyük dinin doğasında dışlayıcılık hem de katı bir dışlayıcılık vardır. Çünkü her biri kendini tek hakikat ve hak olanin temsilcisi kabul eder.

“Dini çoğulculuk ilahi dinlerle ilahi olmayanları eşitler. Bunun yerine “İbrahimi” dinler ile kısmi çoğunluğu ikame etmelidir"5 görüşü, bir temenniden öteye gidemez. Çünkü hiçbir din diğerine doğruluk ve hakikati temsilde kendine rakip olarak görmez. Kaldı ki "İbrahimi” dinler kavramı, İslam dinini Sami geleneğinin sadece bir parçası konumuna düşürür. Çünkü özellikle İslam dini, en son ve en sahih din olma savından dolayı hiçbir dinin devamı ya da parçası olmayı kabul etmez. Nitekim aynı yazar, Maturidi'yi örnek vererek İslam dininin değişmez, fıtri din, hak din, İbrahim dini ve tevhit dini olduğunu söyler. Tevhit ilkesine bağl1 Maturidi, metafizik çoğulculukla ilişkilendirilemez. Maturidi'ye göre çoğulculuk vahyin dindeki yerini sarsar, dini ahlaka indirger. Bu bağlamda dinlerin inanç önermelerini eşitlemesi rölativizmi doğurur. ${ }^{6}$ İslam dininin Hz. İbrahim’le elbette ilişkisi vardır. Çünkü Kur'an 'da Hz. İbrahim'e atıflar vardır. Ancak bu onun Yahudilik ve Hıristiyanlığın doğal bir parçası olduğunu göstermez.

Dini çoğulculuk, dini kapsayıcılık ve dini tekelcilik olmak üzere üç kategoride ele alınan dini çeşitlilik, bazılarına göre sosyolojik bir kavramdır. Tekelciliğe göre tek bir din Hak'tır ve kurtuluşa ancak o erdirir. Dini kapsayıcllık tek Hak dinle birlikte başka dinlerin de Hak ve kurtarıcı olduğunu ileri sürer. Buna kapsayıcılık veya

\footnotetext{
4 Hanefi Özcan, Maturidi'de Dini Çoğulculuk, Marmara Üniversitesi İlahiyat Fakültesi Vakfı Yayınları, İstanbul, 1995, s.140.

5 Hanefi Özcan. agm, a. yer

6 Hanefi Özcan. agm, a.yer.
} 
indirgemecilik de denir. Dini çoğulculuk ise, tüm dinlerin hakikat değeri ve kurtuluşa erdirme açısından eşit olduğunu savlar. "Hatta bunu "dini çokluk" olarak adlandırıp şöyle tanımlayanlar vardır: Dinlerin doğruluk ve yanlışlıklarına bakmaksızın, dinlerin mevcut çokluğunu kuramsal ve metinsel bir olgu olarak rasyonel gören ve yaşama haklarının kaçınılmaz olduğunu ileri süren, farklılıklarını hoş gören bir anlayıştır. ${ }^{8} \mathrm{Bu}$ tanım sosyolojik ve politik bir tanımdır. Farklı dinlerin bir arada yaşamaları, zaman zaman bir takım çekişme, itişme ve hatta savaşlara neden olmuştur. Tarihte meydana gelen bazı çatışmaların dinler arası gerilimlerden kaynaklandığını ve bu nedenle dinlerin barış ve huzur içinde birlikte yaşamalarını salık veren dini çokluk, dini çoğulculuktan farklıdır.

Dinler çokluğu aynı gerçekliğin ve doğruluğun bir boyutu olup farklı ve çelişkili doğruluk değerleri bir üst doğruda birleştirilir, dini çokluğun aksine dinlerin doğruluk iddialarını göreceleştirir. Dini çeşitlilik veya farklılık ise, farklı dinlerin veya inançların kurtuluş için önerdiği alternatif yolları, öğretileri ve değerleri dile getirir. ${ }^{9}$ Dinlerdeki en önemli Gerçek, Tanrı kavramı ya da Tanrı anlayışıdır. Kurtuluş vaadi de bu anlayış etrafında şekillenir.

\section{Bir Süreç Olarak İnanç}

Dinler ve inançlar, bir toplum veya milletin kültürünü oluşturan en önemli unsurdur. Modern yaşamda şu ya da bu dine mensup olmak, kültürlerarası geçirgenlik nedeniyle başkasından ayrıcalıklı olma şansını ortadan kaldırmıştır. İnançların değil de kültürlerin uzlaşı veya çatışma içinde olması, laiklik ilkesini açıklamak için yeni bir kapı açıyor demektir. Çünkü bir dine inanmak, en nihai noktada kişinin kendi iç dünyası içinde olup biten bir süreçtir.

Düşünün ki, en basit olayda bile kişi kendi iç dünyasında, aklında veya vicdanında, hesabı kapatılmamış bir yığın sorgulamalara başvurur. En somut ve

\footnotetext{
M. Kazım Arıcan, Felsefi ve Teolojik Bir Problem Olarak Dini Çeşitlilik, Cumhuriyet Üniversitesi İlahiyat Fakültesi Dergisi, 2011, C. XV, Sayı: 1, ss. 71-98.

8 Arican, agm, A.yer.

9 Arican, agm, A.yer.
} 
gündelik bir durumda kişi, düşündügünü sonuçlandırsa bile, evvelini ve ahirini hala ölçüp tartmayı sürdürür. Üstelik oldubitti diye baktığımız nice sıradan işlerin beklenmedik sonuçlarıyla karşılaşabiliriz. Basit olgu ve olaylarda dahi kesintisiz bir süreç varsa, inanç konusunda bu süreç daha ince ayarlı ve son derece karmaşık olacaktır. Karmaşayı zihninde ve ruhunun derinliklerinde yaşadıkça inanç, her an tazeliğini korur; canlıdır ve bitimsizdir. Olmuş bitmiş bir şey değildir. Sonuçlanmaz ve kalıcılığını da bu iç mücadeleye borçludur. İnanan insanın bu anlamda belki kafası karışık değildir ama zihninde ve ruhunda bin bir çeşit sorular ve cevaplar birbiriyle sürekli çarpışır durur. Kendi içinde süreç olan inanç, başkalarına kesinleşmiş ve en son cevabı bulunmuş bir meta olarak takdim edilemez. İnanç, zihin ve ruhun ortaklaşa beslendikleri, sürekli de beslenmek zorunda oldukları bir erdemlilik halidir. Erdemlilik ise, sonu gelmeyen bir ahlaksal değer mücadelesini gerektirir. Ahlak somut cevaplar ve sonuçlar değil, erdemsizliği, her başkaldırışında öncelikle iç dünyamızda bastırmaya yarayan bir ruh disiplinidir.

\section{Çatışan ya da Uzlaşan Kültürlerdir}

Din, inancın örgütlenmiş biçimidir. Din bize, inancımızı hazır örgütlenmiş olarak sunma iddiasındadır. Ancak bu ne yazık ki bir iddia ve temenniden öte gidememektedir. Çünkü bırakın farklı dinleri, aynı din içinde dahi, farklı inanç örgütlenmesi hep kaçınılmaz tarihsel bir gerçeklik olmuştur. Şiilik, Sünnilik, Alevilik, Zeydilik, Nusayrilik ve yüzlerce mezhep, bu tip örgütlenmenin örnekleridir. Üstelik çokluğundan sayamayacağım bu mezheplerin kendi içinde bile birbirini temelden reddeden mezhep içi inanç blokları vardır.

\section{Peki, Çatışma veya Uzlaşma Nerededir?}

Eğer bir çatışma veya uzlaşmadan söz edeceksek, bunun, inanç örgütlenmelerinin yarattıkları kültürler arasında meydana geldiğinin altını çizmemiz gerekecektir. İşin hakikati böyledir. Hani, uzlaşı varsın kültürler arasında olsun, diye içiminizden geçtiğini biliyorum. Ancak çoğunlukla çatışmalara tanık oluyoruz. İslam dünyasının bu gününden geriye ya da gerisinden bu gününe tarihsel süreci izlediğimizde, aynı din içinde farklı inanç guruplarının yarattıkları kültürlerin hep 
çatışma halinde olduğunu esefle görürüz. Öyleyse, önce dinler arası diyalog veya uzlaşı değil, bir dinin kendi içindeki farklı inançların doğurduğu kültürleri arasında bir uzlaşı olup olmayacağı meselesi üzerine kafa yormak zaruridir. Çatışan inançlar değil, onların yarattığı kültürel unsurlardır. İslam ülkeleri arasındaki bir yandan kısıtlı diyalog ve diğer yandan geniş çatışma, aynı dindeki farklı inançların değil, asıl bu farklı inançların yarattığı farklı kültürlerden kaynaklanmaktadır.

Laiklik işte tam bu noktada doğal olarak kendini dayatmaktadır. İtikadi değil ama siyasi bir tavır olan laiklik, hem aynı din içindeki hem de farklı dinlerdeki farklı inançların yarattıkları kültürleri uzlaştırabilecek henüz daha iyisi icat edilmemiş bir çaredir. Gerçi inançların çatışması ya da uzlaşımını sağlayan laiklik değildir. Çünkü inancın, insanın kendi iç dünyasında ve ruhunun derinliklerinde devam ede gelen diyalektik bir süreç olduğunu söylemiştik. Laikliğin bu noktada insanın vicdanı ve zihinsel süreçleriyle ilgili yapabileceği olumlu ya da olumsuz bir katkısı yoktur. Asıl katkısı, bu inançlardan kalkılarak yaratılan farklı kültürler arasındaki çatışmayı önlemede ve bunu uzlaşıya dönüştürmede görülecektir. Din ve inanç, vicdanda yaşanan kesintisiz ama sonuca bağlanmamış bir iç tecrübe olduğu için, laiklik bu aşamada istese de kişiye müdahil olamaz; hem müdahil olması için de bir sebep yoktur. Laiklik, kültürlerin en önemli kaynağı olan inançları zaten denetleyemez. Ancak onların ürettikleri yaşam biçimleri, ibadet tarz ve şekilleri, davranış ve yapıpetmelerden doğan somut unsurları tüm farklılıkları ve çeşitlilikleriyle uzlaştırmak için zemin hazırlar. Çatışmaları önlemeye çalışır.

Şu halde, dinler ve inançlar, iç süreçler oldukları için, ne diyalog ne de çatışma tesis edebilir; ancak ürettikleri kültürler bakımından olumlu ya da olumsuz etkileşime girebilirler. Eğer Türkiye diğer İslam ülkelerine benzeseydi, çatışma, aynı din içinde farklı inançların çatışmasına sahne olurdu. İslam ülkelerindeki iç çatışmalar, ironik biçimde benim tezimi alt üst etmektedir. Bu hiç olmazsa görünüşte böyledir. İslam içinde Müslümanlar, kabile içinde kabileler ve çöl içinde çöller aynı dinin aynı inancını paylaşmalarına rağmen birbirilerini kıyasıya boğazlamaktadırlar. 
Oysa çatışan inançlar değildir. Çünkü İslam ülkelerinde düşünce ve inanç üretilmeyeli beri asırlar olmuştur. Çatışan, kültürsüzlügüun kültürleridir.

Türkiye çok şanslıdır. Aynı din içinde farklı inançların varlığını ve birlikteliğini sağladığı gibi, bunların ürettikleri farklı kültürleri de laik cumhuriyet geleneğiyle uzlaşım içinde tutabilmektedir. Hatta farklı dinlerin kültürleri ile İslam kültürünü laik tavrı nedeniyle uzlaşmış bir güce dönüştürmesini bilmiştir. Atatürk'ün dehasını, yeniden keşfediyoruz.

\section{İnanç ve Özgürlük Etik Kavramlarıdır}

İnanç ve özgürlük kavramları, insanlık tarihi kadar eskidir ve belli bir dine ait değildir. İnsan, kendisini diğer varlıklardan ayıran belirli özelliklerinden başka, en çok ve belki de en açık biçimde bir ahlak varlığı olmakla öne çıkar. İnanç özgürlüğe bağlıdır. Ancak özgürlük de sorumlulukla birlikte vardır. İnanç, bireyin istediği şeye kısıt getirilmeksizin inanma ihtiyacını karşılar. İnanmanın gereklerini yerine getirme noktasında, inanca özgürlük ve sorumluluk kavramları sosyal ve hukuksal kısıtlar ve sınırlar vaz eder. Çünkü birey toplumun bir parçasıdır. Belki inanma aşamasında bireysel tüm haklarını kendi vicdan ve düşüncesinde kullanma özgürlüğüne sahiptir, ancak inandıklarını uygulama aşaması toplumsal platformda gerçekleşebileceği için, sınırlamalar getirilir. Bireysel olarak inanıp düşündüğümüz her şeyi, bir parçası olduğumuz ve çok farklı düşünce ve kanaatlerin barındığı bir toplumda sınırsız ve sorumsuzca yerine getirmek özgürlük değildir. Kaldı ki bireysel olarak sahip olduğumuz inanç da kendi doğasında sınırsız ve sorumsuz olamaz. Etiğe, hukuka, temel insan, normlara, toplumsal kural ve yaşama düzenine, kısacası ortak insani değerlere aykırı olan hiç bir inanç, özgürlük talebinde bulunamaz. Bilime, apaçık gerçeklere, insancıl düşünce ve kanaatlere taban tabana zıt hiç bir inanç, masum ve makul olamaz. Demek ki inanç için sınırlar aslında daha bireyin vicdan ve kanaatleri oluşurken doğal olarak çizilmek iktiza etmektedir.

İnanç ve özgürlük kavramları doğrudan doğruya ahlak sorunuyla ilgili kavramlardır. Ahlak sorunu ise, insan varlığını en iyi tanımlayan bir düşünce ve duyguyu içerir. İnanmak güven duymak, bel bağlamak, inanılan şey ile kendisi 
arasında mesafenin azaltılması ya da ortadan kaldırılmasıdır. Vurgulamak gerekir ki, inanç insanın en doğal ve en temel ihtiyacıdır. Ahlak sorunu nasıl ki sadece insanla ilgili ise, içinde yer alan inanç da yine yalnız insanla ilgilidir. Çünkü insanın altındaki canlı-cansız varlıklar için ahlakın özgürlük ve sorumluluk gibi bu iki temel kavramı geçerli değildir. Bizim dışımızdaki varlıklar ne özgürdür, ne de sorumludur. Aynı durum Tanrı için de geçerlidir. $O$ ne özgür ne de sorumlu olarak tanımlanamaz. O halde ahlak, ne bizim altımızdaki, ne de üstümüzdeki varlıklar için geçerli bir tanımlama değildir. Bu tanım sadece biz insanlara aittir.

İnanan kişi, eğer gerçekten inanıyorsa tüm varlığıyla kendisini inandığı ilkeye, dine ya da kişiye teslim etmiş demektir. İnsan vicdanında, duygu ve düşüncelerinde meydana gelen bu süreç, vicdani boyutunu koruduğu sürece insanın kendi ruh dünyasına has bir değer olarak varlığını devam ettirir. Ancak hiçbir inanç, insan tekinin ruh dünyasında başlayıp yine orada sona ermez. Ucu açık bir süreç olarak toplumsallaşma, inanç fenomeninin karşı konulamaz doğasını ele verir. Başka bir deyişle, her inanç üç aşağı beş yukarı toplumsallaşmaya doğru gelişme ve kendini açı̆̆a çıkarma itiyadındadır.

İnanç, hurafelerden dini dogmalara, ilkel düzeydeki sanılardan bilimsel bulgulara kadar çok geniş bir tayfı ifade eder. Bilim, din ya da siyasi bir ideoloji, inanca dönüştüğü zaman birbirinden farklı özelliklerini yitirirler; hepsi de vicdani durağanlıktan toplumsallaşma hareketliliğine doğru genişleyip yayılır. Örneğin, dinlerin ve dini inançların dönemi olan Ortaçağlarda, din kapsamı içinde söylenen ve yapıp edilen her şey, kaynakları olan din ya da dinler kadar, dinleşebilmişlerdir.

18. Yüzyıldan itibaren din ve din adamlarının dünyevileşme üzerindeki tesiri kırılınca bilim dinin tahtına oturmuştur. Din, insan ve yaşamı ile ilgili pek çok noktanın aydınlanmasını Tanrı ile mücadele etmek şeklinde yorumlayarak, insanın gücünü sürekli arka planda tutmayı başarmıştır. Vicdanen her şeyin Tanrı'ya havale edilmesinin ötesine geçerek, Tanrı'nın doğa için koyduğu değişmez genel-geçer yasalar da bu havale kapsamına alınarak insanoğlunun neyi ne kadar yapabileceğinin sınırları uzun süre saptanamamıştır. Bilim, dünya yaşamını 
kolaylaştırıcı icatlara ve bilginin teknolojiye aktarılmasında rüştünü ispata yarayan yeni bulgulara eriştikçe, dinin Tanrı hakkında öne sürdüğü güç ile ahlakı kullanarak sürekli sınırlamaya çalıştığı insanın gücünün sınırlarını daha nesnel ölçülerle belirlemeye başladı. Ancak bilim bu başarılarıyla edindiği bilimsel inandırıcılığının, zamanla kendini din yerine koyarak zedelenmesine mani olamadı. Bilime bilimsel metodolojinin sınırları dışına çıkmaması uyarısının yapıldı̆̆ı yeni felsefi düşünce akımları ortaya çıktı. Ancak yazımızın konusu bu akımlar değildir.

Laiklik, bu bağlamda, her türden düşünce ve inanç özgürlüğünü sağlamayı amaçlar. Sözcük olarak "dine ve din adamı sınıfına ait olmayan” şeklinde anlam taşımaktadır. Bu anlam, kilisenin din adına her türlü bilimsel ve düşünsel gelişmeye direnmesi temel alınarak oluşmuştur, diyebiliriz. Bu nedenle laiklik, doğumu ve esinlendiği anlam kaynağ1 göz önüne alınarak din karşıtlığı şeklinde yorumlanmıştır. Oysa siyasi bir tavır olan laiklik, siyaset gibi değişken bir yönetim-çıkar ilişkisinde değerleri esas alan dinin araçsallaşmasını engellemeye yaramaktadır. Şu halde laiklik, sadece dini değil, her türlü inanç ve düşüncenin, kanaat ve duygunun özgürlüğü ile ilgili bir kavramdır. Laiklik, hangi inanç ve düşünce olursa olsun, toplumsallaşma aşamasında müdahil olur. $\mathrm{Bu}$, her inandığımızı ve her düşündüğümüzü uygulamaya girişirken sınırlarla karşılaşacağımız anlamına gelir. Laiklik esasen, her bir inancı diğer inanç ve kanaatler adına denetlemek olmalıdır. Devletlerin resmi inanç ve dinlerinden söz edemeyeceğimize göre, laiklik, hiçbir inancı devlet adına denetlemek olmamalıdır. Diğer inançlara yer açmak için, ilgili inancın toplumsal alanda başka inançlara ket vurmasını önlemek üzere laiklik, işlevselleşir.

\section{Bireysel Hak, Aşiret ya da Grup Adına Talep Edilemez}

Özgürlük, bilinçli birey ya da bireylerin ne talep ettiklerine ilişkin en çarpıcı hakların başında gelir. Doğrudan doğruya insanla ilgilidir ve bu yüzden tamamen ahlaki bir kavramdır. Ahlak bakımından eğitilmiş birey, aynı zamanda aydın insandır. Aydın insan, hak talebini kendisi, birey olarak yapar. Örgüt, grup, dernek ya da aşiret adına veya herhangi bir etnik grup ya da dini bağlılıklar adına dile 
getirilen özgürlük talepleri, doğrudan bireyin özgürleşmesine beklenen faydayı sağlamaz. Birey adına özgürlük talebinde başarı kazansalar da, bu tip grupların, mensubu olan bireylerine bu özgürlükten ne kadarını lütfedecekleri belli değildir. Özellikle inanç özgürlüğü, doğrudan bireyin kendi hak ve sorumlulukları etrafında düşünülmesi gereken bir değer olarak belirlenmelidir. Özgürlük, her şeyden önce bireyseldir. Grup ya da kitle adına özgürlük talepleri, bireyi beklediği özgürlük konusunda hayal kırıklı̆̆ına uğratabilir. Öyleyse özgürlük, doğasında bireysellik ve aydınlanma olmak üzere iki temel özeliği taşımalıdır. Aksi takdirde özgürlük bir ahlak sorunu olarak değil, kitlesel bir sorun olarak algılanır. Birey bu kitlesellik içinde kendi varlığını ve mevcut özgürlüğünü yitirebilir.

\section{İnanç Özgürlüğünün İki Unsuru}

Buna göre, inanç özgürlüğünün sınırlarını iki esas unsur belirler: ilki, içten dışa doğru süreçtir. Birey bu süreçte bilincini kesintisiz aydınlanma ile yeniler. Neyi, neden istediğine dair fikirleri olgunlaşır. Her inandığı ve düşündüğü şeyin eylem alanına geçmesi gerekmediğinin farkına varır. Özgürlüğü kendisi için ister. Bir kişi, grup ya da topluluk için değil, temel insan hakkının bir gereği olarak bu talepte bulunur. Özgürlük isteyen insan teki, bu talebine koşut olarak sorumluluk altına gireceğini hesaplamalıdır. Çünkü özgürlük sorumluluk olmadan düşünülemez. Özgürlük bireysel bir talepse, karşllığı olan sorumluluk da bireyseldir; talep eden kişiye aittir. Özgürlükler, birey adına istenip sorumluklar bir dine, inanç ya da fikir sistemine yüklenemez. Çünkü özgürlük ve sorumluluk kavramları birbirine mütekabiliyet esası üzere bağlıdır.

İkinci esas, dıştan içe doğru olan unsurdur. Bu da laiklikle gerçekleşir. Bireyin elde ettiği özgürlük sonucu karşılaşttğg sorumluluğu, toplumsal alana eylem ve davranış olarak yansıtmasını denetlemek işi, laikliğin müdahale alanı içine girer.

İnanç özgürlüğü dendiği zaman Türk toplumunda ilk anlaşılan şey, dini inanç ve bu inancın gereklerini özgürce yerine getirebilme serbestîsidir. Her din gibi İslamiyet'in de amentüsü ve inanç esasları vardır. Yine her din gibi İslamiyet'inde bir birey, toplum ve devletle ilgili yorumlara dayalı bir yığın tarihsel literatürü 
elimizdedir. Bununla birlikte, özgürlük taleplerinin, inandıklarımızın hukuksal ve siyasal alanlarla işlevselleşmelerine kadar uzanan sınırsızlığı göz önüne alınınca, bu ucu açık özgürlük istemi, aynı toplumda yaşayan başka din ve inançları kısıtlayarak ancak gerçekleşebilir. Din ve Tanrı adına istenen özgürlüklerin sınırı olmaz. Oysa din, kendi içinde sınırlıdır ve o da insan içindir. Aynı insan, özgürlüğü kendisi için değil de Tanrı ve din adına talep ettiği için, başka insanlar üzerinde kurmayı tasarladığı egemenlikte kesinlikle sınır tanımayacaktır. Tarih boyunca bitmek tükenmek bilmeyen farklı dinler arasındaki savaşlar ve hatta aynı din içindeki mezheplerin kıyasıya boğuşmaları bunun bariz kanıtlarındandır. İnanç özgürlüğünün doğal sınırları, içten dışa bireysel sorumlulukla; dıştan içe de laiklikle çizilmelidir.

\section{Özgürlük İnsana Özgü Bir Değerdir}

Felsefe, en çok insanın kendi hakkında düşünmesi demektir. İnsan önce kendini keşfetmeli ki onu çepeçevre saran evreni, varlık dünyasını ve içinde yaşadığı toplumu hakkıyla anlayabilsin. Her bilim, insanı kendi sınırları içinde tanımlar. Hukuktan siyasete ve kimyadan fizik bilimlerine kadar birbirinden farklı insan tanımlarına rastlarız. Her biri kendi ilke ve yöntemlerine göre bu tanımı yapar. Kimi aklı, kimi düşüncesi ve kimi de eylem ve davranışlarını konu alır. Ancak insanı, tüm hakikatiyle tanımlayan tek disiplin, ahlaktır. Ahlak dışındaki tüm tanımlarda biz insanların diğer varlıklarla ortak bir veya birkaç yönüne rastlayabiliriz. Oysa ahlak konusunda hiçbir varlıkla ortak bir yönümüz yoktur. Hatta ahlak Allah için bile geçerli değildir. Çünkü O bile bir ahlak varlığı olarak tanımlanamaz. Ahlak varlığı olan tek canlı, insandır. İçinden geçirdiği niyeti, duygu ve düşünceleri ve dolayısıyla bunların yaşama geçirilmesi olan tüm eylemleriyle insan, bir ahlak varlığıdır.

\section{Sorumlu Varlık Olarak İnsan}

Allah ahlak varlığı değildir, dedim. Çünkü yapıp ettiklerinden, niyet ve tasarılarından kimseye karşı sorumlu değildir. Sorumlu olsaydı, O'nun için de bir özgürlük talebi olduğunu ileri sürmemiz gerekecekti. Ama bu noktada Allah özgür değildir sonucunu çıkarmak mantık dışı olur. Çünkü ne özgürlük ne de onun doğal 
gereği olan sorumluluk, Allah hakkında söylenemez. Allah'ın bir ahlak varlığı olarak tanımlanmadığını söylemek, O'nun ahlak erdemlerine aykırı kaza ve kader yarattığı anlamına gelmez. Allah, ahlak karşıtı bir varlık olarak da görülemez. Özgürlük ancak sorumlu varlık için istenen bir değerdir. Yaptıklarından ve eylediklerinden başkalarına karşı sorumlu olmak, Allah için düşünülemez. Aynı şekilde, insan dışındaki diğer varlıklar için de söz konusu olamaz. Öyleyse insan, sorumlu olduğu için özgür olmalı, özgür olduğu için de sorumluluk duymalıdır. Allah'ın yapıpetmelerinden sorumlu olduğunu ve dolayısıyla 'sonuçlarına katlanmak zorunda bulunduğunu' ileri sürmek gibi çelişki, O'nu Allah olarak bilmemize manidir. Diğer varlıkları da 'niyetleri ve eylemleri yüzünden yargılayıp sonuçlarından sorumlu tutmak", bir başka çelişkiye düşmek olur. O halde akll, düşüncesi ve eylemleriyle sorumlu olan; bu nedenle de yaptıklarının sonucuna katlamak durumunda olan tek varlık, insandan başkası değildir. Bu sorumluluk, ister yaşadığı topluma, ister inandığı dine ve Tanrı'ya karşı olsun, neticede insana şu ya da bu yükümlülüğü dayatır. Ödül veya cezaya muhatap kılar.

\section{Hukuk Ahlaktan Ayrilamaz Ya da Ahlaksız Bir Hukuk Olmaz}

Her hukuki olan mutlaka ahlaki ilkelere uygun olmalıdır. Ama her ahlaki olan, kesinlikle hukuki olmak zorunda değildir. Çünkü hukuk ilham ve yönergelerini ahlaktan almak zorundadır ve her adımda ahlaka muhtaçtır. Her türlü ahlaki niyet ve eylem hukuka yansımaz. Bunların ancak bir kısmı hukukileşebilir. Ahlak tümdengelimsel, hukuk ise tümevarımsaldır. Yani ahlak genel ve kapsayıcı ilke ve kurallar vazeder; hukuk da olgu ve görüngülerden hareketle bu genel ilkelere uygun yargılara ulaşmaya çalışır. Görünüşte hukukun yaptırımı ahlaka göre daha etkilidir. Ancak gerçekte böyle değildir. Hukuk sizi, çoğu zaman mahkeme, karşı taraf ve yargıçlar nezdinde yargılar. Oysa ahlak sizi, tüm toplumda ve hemen her bireyin vicdanlarında mahkûm eder. Hukuki ceza ne de olsa, süre ve mekâna bağlıdır, ama ahlaki cezaların ne süre ve mekânları vardır; nerde başlar nerde biter, belli olmaz. Vicdanları ve toplumsal sağduyuyu tamir etmek bir ömrü alabilir. Hukuku erdemsiz bir hükme mahkûm etmek, ahlakı hukukun emrine vermek; halk 
deyişiyle aslanı kediye boğdurmak demektir. Yargıtay'ın N.Ç. adlı mağdure hakkında verdiği hüküm, tam olarak bu durumu açıklar. Ahlakın alanı hukuktan daha geniş ve hukuku belirleyici konumda iken, bu yanlış kararla dar hukuk adeta geniş olan ahlaka ahlak dersi vermiştir. Eğer böyle bir hukuki kararın ardında bir siyasi ideoloji varsa, hukuk ahlaka, siyaset de hukuka tecavüz etmiş olmaktadır.

\section{Özgürlük Zihinde Başlar}

Özgürlük talebinde bulunmadan önce, ona inanıp inanmadığımızı; elde ettiğimiz takdirde özgürlüğün dayanılmaz sorumluluğunu taşıyı taşıyamayacağımızı iyi hesap etmemiz lazımdır. Özgürlükten önce sorumsuz isek, özgürlüğün bize daha fazla sorumsuzluk sağlayacağını beklemek, hayaldir. Çünkü özgürlük daha fazla sorumluluk duygusuna hazır hale gelmemiz gerektiğini dikte eder. Başkasından özgürlük talep etmeden önce, zihinsel olarak özgür olup olmadığımızı iyice irdelemek gerekir. Acaba biz, başkasının elinde bulunup da ondan dilendiğimiz özgürlükten daha azına mı sahibiz? Zihnimizde birey olarak özgür olduğumuzu yeterince inanıyor muyuz? Başkasının bize vereceği özgürlük, bizim kendimize layık gördüğümüzden ileri bir aşamayı mı ifade ediyor? Benim zihnimdeki özgürlük sınırlarının, talep ettiğim özgürlüğün sınırlarından daha geniş ve mutluluk verici olduğundan gerçekten emin miyiz?

Türk toplumundaki özgürlük taleplerinin zihinsel fizibilitesi tam yapılmamıştır. Özgürlük isteyen dini, etnik ya da bölgesel aktörler, kendi iç dünyalarında talep ettiklerinden fazla bir özgürlük bilincine sahip olup olmadıklarını dönüp kendilerine sormalıdırlar. Dindar insanların en az özgür topluluk olduğunu ileri sürenlere bakalım. Cemaat ve sivil toplum örgütleri adına bu düşünceleri öne sürerken, kendi iç dünyalarında, zihinsel ve ahlaki olarak özgürlüğe ne denli bağlı oldukları tartışılır. Koskoca İslamiyet'i belli bir grup veya topluluk sınırları içinde yorumlamaya mahkûm eden gruplar, kendi zihinsel süreçlerinde başka yorumlara açık kapı bırakmazken, farklı anlayışlara hiçbir müsamaha göstermezken, nasıl olur da bu taleplerinde samimi olabilirler? Kendi zihinlerine ve çevrelerine, hali hazırda sahip oldukları özgürlüğü bile çok gören bu insanlar, 
istedikleri 'fazla'yı nerede değerlendireceklerdir? Aynı dine inanmak sınırı bile, aynı gruba göre inanmakla daha da daraltılmışken, elde edecekleri 'fazla özgürlüğü' ne yapacaklarını anlatmalıdırlar. Asıl sorun, zihinlerdeki mahkûmiyettir. Kendi zihnini ve çevresini özgürlüğe layık görmeyeni, kimse özgürlük talebinde samimi ve gerçekçi görmez.

Etnik ve bölgesel özgürlük talepleri de bu örnekten irağa düşmez. Aşiret yapısı, kan davası, kadına karşı şiddet, ırk fanatizmine düğümlenmiş ilkel ve saldırgan siyaset biçimiyle özgürlük talep ederken, adama, 'sen önce bu çağdışı ve köleci bağlarından özgürlük talep ettin mi' diye sorarlar.

Özgürlük, önce zihinde başlar; bireyi inşa eder. Özgürlük, bir topluluk, grup ya da cemaat, etnik ya da bölgesel kapsamda talep edilmezden önce, zihinsel ve ahlaki olarak talep edilir. Özgürlük önce bireyi yaratır. Özgür bireylerden oluşan bir topluluk varsa, o da millettir; aşiret ya da cemaat değildir. Aşiret veya küçük gruplar için özgürlük istemek, var olanı sindirememiş olduğu kadar, istenilenin de 'ne işine yarayacağını' bilmemek demektir.

Sorumsuz bir özgürlük, başıboş bir eyleme yol açar. Özgürlük istemek, insana hastır. İnsanın en temel hakkı elbette özgürlüktür. Ama ahlaki bir varlık olarak bu talepte bulunduğunu hiç unutmamak lazımdır. İsterken 'insan', yararlanırken 'diğer canlılar' ya da 'Tanrı' imişçesine davranmak, insanın ahlaki bir varlık olarak tanımıyla kökten çelişir. Ahlakı hukukun, hukuku da siyasetin vesayetinden özgürleştirmek, bireyi aşiret ve grupların vesayetinden özgürleştirmekle aynıdır.

Birey, özgürlüğü kendi için istemelidir. Çünkü on bu verildiği zaman, sınırlarını kendi tayin etme hakkını elde etmiş olur. Aksi halde, birey topluluk ya da grup için özgürlük talebiyle ortaya çıkarsa ve mensubu bulunduğu grup sonuçta istediğini alırsa, bunda emeği olan bireye o özgürlükten ne kadarını lütfedeceği belli değildir. Grubu için talep ettiği özgürlüğü, bu kez birey, mensubu olduğu grubun elinden kurtarmak için mücadele etmek zorunda kalacaktır.

İnanç, Siyaset ve Tutkuların Aleti Olamaz. 
1920'ler sonunda Cumhuriyet'in laik temeller üzerine oturtulması ardından hükümet 1930'lu yıllarda dikkatinin büyük kısmını ideolojik temellerine adadı. İlk olarak 24 Eylül 1931'deki bir konuşmasında Atatürk, Cumhuriyetçilik, Milliyetçilik, Halkçılık, Devletçilik, Laiklik ve İnkılâpçılığın Kemalizm'in temel ilkeleri olduğunu ilan etti. ${ }^{10}$

Bu ilkeler aynı zamanda inanç ve düşünce özgürlüğünün siyasi ve düşünsel temelleridir. Ben bunlar arasında özellikle Milliyetçilik ilkesinin düşünce ve inanç özgürlüğünün esaslı şartlarından biri olduğunu belirteceğim ve muhafazakârlıkla kıyaslayacağım.

\section{İnanç Özgürlüğü ve Sınırları Açısından Milliyetçilik ve Muhafazakârlık}

Geçmiş çağlarda, birer değişiklik aracıydılar. Doğmakta olan bir din hareketi, baştan aşağı değişiklik ve denemelerle doludur ve her yönden yeni görüşlere açıktır. İslamiyet, doğduğu zaman, örgütlendirici ve modernleştirici bir ortam meydana getirmiştir. Ancak diğer dinler gibi İslamiyet de muhafazakârlaşmaktan kurtulamamıştır. Oysa bir dinin muhafazakârlaşması, can suyunun pıhtılaşması gibidir. ${ }^{11}$

Muhafazakârlar, ontolojik bakımdan bireyin zayıf ve aile, din, gelenek gibi kurumlarla desteklenmesi gereken bir varlık olduğuna inanırlar. Epistemolojik bakımdan bireyin akıl kapasitesinin sınırlılığını vurgulayarak, tarihi tecrübenin ve pratik bilginin soyut akıl yürütmeye tercih edilebilir olduğunu kabul ederler. Siyasi bakımdan da hiçbir biçimde her şeye muktedir olduğuna inanmadıkları soyut akıl yürütmelerle üretilen "devasa projeler"den ve siyaset alanının ara kurumlar aleyhine genişletilmesinden kaygı duyarlar.

Milliyetçilik ve muhafazakârlık birbiriyle uyuşmaz. Milliyetçilik inkılâpçıdır, muhafazakârlık ise mevcut statükonun ve onun getirdiği şartların korunmasını ideolojik olarak savunur. Milliyetçilik ilkesi, toplumsal ilerleme ve gelişme için

\footnotetext{
10 Soner Çağaptay, Türkiye'de İslam, Laiklik ve Milliyetçilik Türk Kimdir? Çvr. Özgür Bircan, İstanbul Bilgi Üniversitesi Yayınları, 2006, s. 17.

11 Bkz. Eric Hoffer, Kesin İnançlılar, çvr. Erkıl Günur, İm Yayınları, İstanbul, 2005, s.30.
} 
vazgeçilmez bir ilkedir. Herhangi bir etnik kökene göndermede bulunmaz. Türk Milliyetçiliği, kültürel ve tarihsel birlik ve beraberliği resmeder. Bununla da kalmaz; Türk toplumu içinde mevcut farklı etnik kökenlerin, din ve mezheplerin birbirlerine tasallut ve tahakkümlerinin de önüne geçer. Türklük bu sebeple şemsiye bir kimliktir; ırki kökene dayalı hiç bir kimlik, belirli bir din ya da mezhebe bağlı hiçbir din yorumu diğerlerinin üstünde ya da altında olmak imtiyazı ya da mahrumiyeti ile karşı karşıya değildir. Milliyetçilik ilkesi bu bağlamda tüm farklı etnisitelere geniş bir özgürlük alanı yaratmakla kalmaz; mevcut bütün din ve mezheplere, hatta aynı din içindeki farklı anlayışlara da inanç özgürlüğü alanı yaratır. Milliyetçilik milli özgürlükle birlikte toplumsal ve bireysel özgürlüğün de can suyudur.

Gerek Fransız, gerekse Rus devrimlerinin birer milliyetçi hareket haline dönüşmüş olmaları göstermektedir ki, modern çağda milliyetçilik, kitle heyecanının en yoğun ve en sürekli kaynağıdır. Devrimci heyecanın başlatmış olduğu büyük değişiklikler zincirine son verilmek isteniyorsa, milliyetçi heyecanın önü alınmalıdır. ${ }^{12}$

Japon milliyetçiliğinin yeniden canlanma ruhundan yararlanılmasaydı, Japonya'nın olağanüstü kalkınması belki de mümkün olmazdı. Batı Avrupa ülkelerinin özellikle Almanya'nın hızla modernleştirilmesinin de, milliyetçi heyecanın iyi bir şekilde teşvik edilmesiyle kolaylaştırıldığı düşünülebilir. Mevcut belirtilere göre bir yargıya varıldığında, Asya ülkelerinin uyanışını gerçekleştirecek ortam, milliyetçi hareketlerden başka bir şey olmayacaktır. Mustafa Kemal Atatürk'ün hemen hemen bir gecede Türkiye'yi modernleştirmesine imkân veren durum, samimi bir milliyetçi hareketin doğuşu olmuştur. ${ }^{13}$

1924 Anayasası Türk sözcüğünün siyasal ve sosyal yönden çok açı tanımını yapmıştır: “Türkiye halkına din ve ırk farkı olmaksızın vatandaşlık yönüyle ıtlak olunur." (md. 88). Anayasa, dinsel ve ırksal farklılıkların bir anlam taşımadığını yalın bir dille belirtmiştir. Bu tanım, Cumhuriyet yönetiminin milliyetçilik anlayışını da

\footnotetext{
Eric Hoffer, age, s. 31.

13 Eric Hoffer, age, s. 32.
} 
ortaya koymaktadır. Atatürk ilkelerinden biri olan milliyetçilik, sömürgecilik ve yayılmacılığa karşı, insani ve cihanşümul bir öz taşır, soyu ve dini temel alan bir anlayışa dayanmaz. ${ }^{14}$

\section{Millet: Muhafazakâr, Ulus: Modernist?}

Millet ve ulus kavramları farklı kesimler tarafından kullanılmakla birlikte esasen aynı anlamdadır. Türkiye Cumhuriyeti'nin özel konumu ve tarihsel olayların gelişimi sonucunda aynı anlama sahip olan bu iki kavram değişik dönemlerde devreye girmiştir. Milliyetçilik kavramı millet sözcüğünden kaynaklanmaktadır. Ümmet sözcüğü bir dine dayanan insanlar topluluğu demektir. Zaman içinde dini toplumdan laik düzene geçilirken ümmet kavramının yerini millet kavramı almıştır. Ne var ki daha sonraları da millet kavramının ümmet kavramını çağrıştırması nedeniyle Türklerin Orta Asya döneminden gelen ve Orhun Kitabeleri'nde yer alan 'ulaş' kavramından yararlanılarak ulus sözcüğü türetilmiştir. Türklerin İslamiyet'i kabul etmelerinden önceki bir dönemden gelen bu kavram din dişı bir birlikteliği ifade ettiği için laik ve çağdaş bir devlet kurmak üzere yola çıkan cumhuriyetimizin kurucuları tarafından benimsenmiştir. Sonraki yıllarda toplumun sağcı kesimleri, muhafazakârlar ve dindarlar millet ve milliyetçilik kavramlarını kullanmışlar, Türk toplumun ilerici ve çağdaş kesimleri ile laikliği benimseyen gruplar ve sol düşünceli aydınlar ise ulus ve ulusalcılık kavramlarını sıcak karşılayarak kullanmışlardır. ${ }^{15}$

\section{Atatürk'e Göre Özgürlük ve Sınırları}

Atatürk diyor ki:

“İslam dinini, yüzyıllardan beri alışılageldiği şekilde bir siyaset aracı durumundan uzaklaştırmak ve yüceltmek gerekli olduğu gerçeğini görüyoruz. Mukaddes ve ilahi inançlarımızı ve vicdani değerlerimizi karanlık ve kararsız olan ve her türlü çıkar ve tutkulara görüntü sahnesi olan siyasal işlerden ve siyasetin bütün kısımlarından bir an evvel ve kesin şekilde kurtarmak, milletin dünyevi ve

\footnotetext{
14 Bkz. Fethi Karaduman, Çöküş ve Doğuş, Atatürk Devrimi, Günizi Yayıncılık, İstanbul, 2006, ss. 609-612.

15 Anıl Çeçen, “Ulusalcılık-Milliyetçilik Kavramları", (Milliyetçilik: Neden Şimdi?, Hazırlayan: Çetin Yetkin, Yar Yayınları, Antalya, 2006 içinde), ss. 54-63.
} 
uhrevi mutluluğunun emrettiği bir zorunluluktur. Ancak bu yolla İslam dininin yüksekliği belirir." 16

\section{Vicdan Özgürlüğü}

Atatürk diyor ki:

“Her birey istediğini düşünmek, istediğine inanmak kendine özgü siyasal bir fikre sahip olmak, seçtiği bir dinin gereklerini yapmak veya yapmamak hak ve özgürlügüne sahiptir. Kimsenin fikrine ve vicdanına egemen olunamaz. Vicdan özgürlüğü sınırsız ve sataşılmaz, bireyin doğal haklarının en önemlilerinden tanınmalıdır. Din ve mezhep, herkesin vicdanına kalmış bir iştir. Hiçbir kimse hiçbir kimseyi ne bir din, ne de mezhep kabulüne zorlayabilir. Din ve mezhep, hiçbir zaman siyaset aracı olarak kullanılamaz."17

\section{İnanç Özgürlüğ̈̈}

İslam dini anlaşılmayı amaçlar. Kur'an'da " bu kitap anlaşılsın diye indirilmiştir, diye belirtilir. İnanç özgürlüğü işte anlaşılmanın sınırları ölçüsünde insanidir ve insana göredir. Ne var ki dinin anlaşılması, kötü niyetli kimselerce kitleler üzerinde haklı olarak etkili olmayan bir yoldur. Tam tersine bu kimseler dinin anlaşılmadığı oranda etkili olabileceğini keşfetmişlerdir. O yüzden insanların dini yeterince hatta hiçbir şekilde anlamalarını arzu etmezler. Bunun için ellerinden geleni yaparak önce onların zihinsel ve ruhsal özgürlüklerine, dini öne sürerek bir takım engeller koyarlar ki insanlar dinin doğasında onu anlamamak olduğu yanılgısına düşürülürler.

Böylece bir öğretinin etkililik derecesi hakkında varılacak yargı, onun derinliği, yüceliği ve doğruluğundan değil, fertleri kendi nefsinden ve gerçek çevresinden ne kadar iyi ayırabildiğinden çıkarılmalıdır. Pascal'ın etkili bir din hakkında söylediği, etkili bir öğreti için de kabul edilebilir: “Etkili bir din, doğaya, sağduyuya ve zevk almaya karşı olmalıdır." Bu suretle açıkça görülmektedir ki bir

16 Utkan Kocatürk, Atatürk'ün Fikir ve Düşünceleri, Atatürk Araştırma Merkezi, Üçüncü Basım, Ankara, 2007; s. 192.

17 Utkan Kocatürk, age, s. 193. 
öğreti etkili olabilmek için, anlaşılmaz fakat inanılır olmalıdır. İnsanlar sadece anlamadıkları şeylerden kesinlikle emin olurlar. Anlaşılabilir bir öğreti güçten yoksundur. ${ }^{18}$

Din kimseyi inanmaya ve inandıklarını tatbike zorlamaz. İnanmak zorunlu olmadığı gibi inandığını yapıp yapmamak da zorunlu değildir.

"Dinde zorlama yoktur."19 "Ey Muhammed! Rabbin dileseydi, yeryüzünde bulunanların hepsi inanırd1. Öyle iken inanmaya sen mi zorlayacaksın?" 20

İslam kelamı, başka bir deyişle İslam ilahiyatı, Allah'ın iradesini ikiye ayırır. İlki, Tekvini İrade'dir: doğum, ölüm, güneşin doğup batması, mevsimlerin birbiri ardına gelmesi gibi doğa yasalarıyla ilgili olan iradededir ki burada zaten kendiliğinden zorlama vardır. Canlı cansız tüm varlıklar, doğal süreç içinde tekvini iradeye ister istemez bağlıdır. Hiçbir varlık bu irade dışında ve ona rağmen ne var olabilir, ne de ölebilir. İkincisi Teşrii İradedir ki bunda ilahi ve doğal bir zorlama söz konusu değildir. Allah bu iradesiyle, insanların kendine ve yolladığı dinlere inanmalarını arzu eder, ama yaratılış ve doğa ile ilgili iradesinde olduğu gibi, kimseyi doğa kanunlarına boyun eğdirdiği gibi inanmaya boyun eğdirmez, her insanı inanç konusunda özgür bırakır. İnanmalarını arzu etmesi, insanların iyiliğini dilemesinden dolayıdır. İsteseydi, doğa kanunlarındaki doğal zorlamayı bu iradesiyle de gerçekleştirebilirdi. Ancak bu zorlamayı kendi şanına uygun görmemiş; insana değer vermekle kalmayıp onun özgür tercihine de değer atfetmiştir. Kimseyi doğa yasalarındaki zorunlulukta olduğu gibi zorla inandırmayı kendi yüceliğine münasip görmeyen Allah, bu konuda bu ve benzeri birçok ayette ${ }^{21}$ ifade edildiği gibi kendi Peygamberine bile herhangi bir yetki ya da izin vermemiştir. Dolayısıyla inanç özgürlüğünü yine Allah kendi katında ve şanında himayesi altına almıştır.

Türkiye'de inanç ve düşünce özgürlüğü, uluslaşma ve dolayısıyla bireyleşme süreçlerinde yaşadığımız toplumsal sancılar hafiflediği zaman yerli yerine

18 Eric Hoffer, age, s. 122.

19 Bakara, 2/ 256.

20 Maide, 5/ 99.

21 Mesela bkz. Al-i İmran; 3/20; Nahl, 16/ 35, 82; Nur, 24/ 54; Ankebut, 29/18; Ğaşiye, 88/21-22. 
oturacaktır. Uluslaşma ve buna bağlı olarak bireyleşme gerçekleşmeden inanç ve düşüncenin konusu olan konuların doğasında olgunlaşma beklenemez. Bireye sunulan inanç ve düşünce konularının bilim, aydınlanma ve insan merkezli felsefi birikimle yeniden gözden geçirilmesi, özgürlük ve onun sınırlarını da doğal olarak yeniden belirleyecektir. Felsefi sorgulamaya karşı derin kuşku, bilimsel yöntembilim eksikliği, okuma-yazma oranındaki düşük seviye, kısacası bilgi aleyhine inancın her şeyi belirlemesi gibi düşünsel sorunlar aşılmadıkça; aşiret, bölge ve etnik temelli sosyal yapının ulusal yapıya beklenen hızda dönüşememesiyle ilgili sosyolojik problemler çözülmedikçe, inanç özgürlüğü ve sınırları her zaman birbirini tamamlayan unsurlar olarak değil, birbirine karşıt iki cephe olarak konumlandırilacaktır.

\section{Kaynakça}

\section{Kur'an-1 Kerim}

Arıcan, M. Kazım, Felsefi ve Teolojik Bir Problem Olarak Dini Çeşitlilik, Cumhuriyet Üniversitesi İlahiyat Fakültesi Dergisi, 2011, C. XV, Sayı: 1.

Basinger, David, Religious Diversity A Philosophical Assessment, Ashgate, NY., 2002 Çağaptay, Soner, Türkiye'de İslam, Laiklik ve Milliyetçilik Türk Kimdir? Çvr. Özgür Bircan, İstanbul Bilgi Üniversitesi Yayınları, 2006.

Çeçen, Anıl, "Ulusalc1lı-Milliyetçilik Kavramları", (Milliyetçilik: Neden Şimdi?, Hazırlayan: Çetin Yetkin, Yar Yayınları, Antalya, 2006 içinde).

Hoffer, Eric, Kesin İnançlılar, çvr. Erkıl Günur, İm Yayınları, İstanbul, 2005.

Karaduman, Fethi, Çöküş ve Doğuş, Atatürk Devrimi, Günizi Yayıncılık, İstanbul, 2006.

Kocatürk, Utkan, Atatürk'ün Fikir ve Düşünceleri, Atatürk Araştırma Merkezi, Üçüncü Basım, Ankara, 2007.

Özcan, Hanefi, Maturidi'de Dini Çoğulculuk, Marmara Üniversitesi İlahiyat Fakültesi Vakfı Yayınları, İstanbul, 1995. 
Volney, Harabeler, Çev. Kazım Akses, Milli Eğitim Basımevi, İstanbul, 1946. 